\title{
Analysis of Obstacles and Challenges Encountered by Parents in Roma Communities in Early Enrolment: Case of Slovakia
}

\author{
Lýdia Mirgová ${ }^{1}$ \\ Catholic University in Ružomebrok, Pedagogical Faculty, SLOVAKIA
}

Received: 28 February 2021 - Accepted: 13 April 2021 • Published Online: 23 April 2021

\section{Abstract}

The theme of this article is informing about existing policies, practices and situation (including gender disaggregated statistics) with regard to the enrolment of Roma children in pre-school and primary school in the target localities of Vel'ká Lomnica and Toporec. It is done by an analysis of the obstacles and challenges encountered in their adequate and timely enrolment, as well as identified solutions a description of the implemented activities and their outputs; and recommendations on how to overcome the identified obstacles and to establish long-term solutions ensuring equal access of Roma children to quality and non-segregated education.

Keywords: Roma children, equal access, education, obstacles.

1. Existing policies, practices and situation in Slovakia with regard to the enrolment of Roma children in pre-school and primary school in the target localities

Following the legislative changes in Act no. 245/2008 Coll. on education and training (Education Act), enrolment takes place from 1 April to 30 April, which precedes the beginning of the school year in which the child is to start compulsory education. Admission of children into kindergartens is regulated by the following legislation.

Act no. 596/2003 Coll. on state administration in education and school selfgovernment. In this context, Act No. 597/2003 Coll. on the financing of primary and secondary schools and school facilities increases the amount of the contribution to education of children in kindergartens, due to changes in the State Educational Program for Pre-primary Education in kindergarten, as well as increased demands in personnel and material-technical provision. The kindergarten is usually set up with a minimum of ten children. Pre-school education is carried out according to the school educational program. There are two types of kindergarten in terms of organization of education: (a) half-day education; or (b) all-day education.

Law no. 209/2019 regulates compulsory pre-school education, which shall enter into force on 1 January 2021. The Act introduces compulsory pre-school education in kindergartens as

${ }^{1} \mathrm{PhD}$ student at Pedagogical Faculty.

(C) Authors. Terms and conditions of Creative Commons Attribution 4.0 International (CC BY 4.0) apply. Correspondence: Lýdia Mirgová, Catholic University in Ružomebrok, Pedagogical Faculty, SLOVAKIA. E-mail: Lydia3623@gmail.com. 
part of compulsory education for five-year-old. Compulsory education extends from the current ten years to eleven years and will include one school year in kindergarten. If, after the expiry of the one-year compulsory pre-school education, the child is not entitled to continue compulsory education at primary school, then he/she shall, at the nursery school's discretion, repeat the preschool education in the nursery school. The institutes of "postponement of compulsory schooling" are abolished, and the possibility of setting up a zero grade is also abolished. The statutory representative of the child is obliged to enroll the child for compulsory education in kindergarten and for continuing compulsory education in primary school.

There are 2,700 inhabitants in Vel'ká Lomnica and 2,200 out of them are Roma. In Toporec, there are 1,750 inhabitants and 750 out of them are Roma.

In Vel'ká Lomnica, the official data regarding enrollment are as follows:

(1) The number of Roma boys and girls in the locality who are of primary school age in the current academic year 2019-2020 versus those who are actually enrolled $80 / 80$ ( 36 girls and 44 boys);

(2) The number of Roma boys and girls in the locality who are of primary school age in the upcoming academic year 2020-2021 - 95 (55 boys and 41 girls);

(3) The number of Roma boys and girls in the locality who are of preschool education age in the current academic year 2019-2020 versus those who are actually enrolled -64 ( 24 girls and 40 boys) /59 (24 girls and 35 boys);

(4) The number of Roma boys and girls in the locality who are of preschool age in the upcoming academic year 2020-2021 - 120 (52 girls and 68 boys).

In Toporec, the official data regarding the enrollment is as follows:

(1) The number of Roma boys and girls in the locality who are of primary school age in the current academic year 2019-2020 versus those who are actually enrolled 27/27 (14 boys and 13 girls);

(2) What is the number of Roma boys and girls in the locality who are of primary school age in the upcoming academic year 2020-2021 - 28 (15 girls and 13 boys);

(3) What is the number of Roma boys and girls in the locality who are of preschool education age in the current academic year 2019-2020 versus those who are actually enrolled -53 ( 24 girls and 29 boys)/31 (13 girls and 18 boys);

(4) What is the number of Roma boys and girls in the locality who are of preschool age in the upcoming academic year 2020-2021 - 52 (22 girls and 30 boys).

In the kindergarten and primary school, neither parents nor teachers make any difference between boys and girls. In both schools, teachers know and are familiar with the procedures of enrollment. As mentioned, they are involved in the enrollment process, providing support to the parents.

Roma parents perceive preschool education to be of less importance. Here are some of the arguments from the parents in Toporec and Velká Lomnica that I found in personal interviews with them:

In the case where there are larger numbers of children, the family does not have a sufficient amount of money for each child. Roma mothers often stay at home, so they do not want to put their children into kindergarten. Mothers often claim that they do not have the necessary documents, such as a birth certificates or a health insurance card. Mothers also complain about kindergarten teachers, as when during the first few weeks, the child is crying the teachers will not allow the mother to go into the kindergarten for at least 1-2 hours, because this disrupts the school order. The 
language barrier is an also a major problem. Other problems include the child's ability to adapt and difficulties in commuting.

Regarding further habits, such as eating, children are not used to the meals in kindergarten, as different meals are prepared at home. 4-5-year-old children are not used to eating by themselves. In kindergarten, it is mandatory to sleep in the afternoon, the child must lie down, which is a problem for many children who do not want to sleep. In the case of mixed classes, nonRoma children often refuse to sit with Roma children, sleep next to them, play with them, or hold hands when on a walk.

\subsection{Poverty}

Despite the fact that the overall standard of living has increased, one of the obstacles is the lack of financial resources among many Roma parents. Officially, school is free of charge, but this is not the reality. In reality, there are many hidden costs. Parents need to pay consumables, auxiliary manuals and extracurricular activities (trips to the cinema, etc.). All of these are costs, in theory optional, but in reality, those who do not pay are stigmatize. They end up being treated differently by the teachers, parents and other children. Poor housing conditions and a lack of immunizations cause many Roma children to be more sensitive to a cold, viruses, flu and even childhood illnesses that are, in some cases, fatal. During the winter months, many Roma children attend kindergarten less because of colds. Children from poor families do not have sufficient clothing in winter.

\subsection{Financial requirements in Toporec}

\section{Kindergarten 1}

Financial obligations of parents:

1. Tuition fee -4 euro;

2. Monthly diet - 20 euro;

3. Parents buy toiletries, slippers, pajamas, towel - 30 euro.

\section{Kindergarten 2}

Financial obligations of parents:

1. Tuition fee -5 euro;

2. Monthly diet - 1 euro (If parents are unemployed and if they prove to the principal of the kindergarten that they are in material need, they pay only 1 euro a month for lunch);

3. Parents buy toiletries, slippers, towel - 30 euro.

\section{Primary school}

Financial obligations of parents:

1. Tuition fee - 4 euro;

2. Monthly diet - 20 euro;

3. Parents buy toiletries, slippers, towel and other - 30 euro. 


\subsection{Financial requirements in Vel'ká Lomnica}

\section{Kindergarten}

Financial obligations of parents:

1. Tuition fee -8 euro;

2. Monthly diet - 31 euro;

3. Parents buy toiletries, slippers, pajamas, towel and other items - approx. 30 euro.

If parents are unemployed and if they prove to the principal of the kindergarten that they are in material need, they pay only 1 euro a month for lunch.

\section{Primary school}

Financial obligations of parents:

1. Tuition fee -8 euro;

2. Monthly diet - 31 euro;

3. Parents buy toiletries, towel and other items - approx. 30 euro.

Free lunches have been introduced since this year. These are provided for all children from 5 years of age. The state contributes only to the purchase of food, the rest is financed by the municipality. The result is that if they have been paying 1 euro until now, from now on they pay between 5 and 8 euro.

\subsection{Technical barriers to enrolment}

The application form is available on the kindergarten's website or in printed form from the kindergarten. A common obstacle to enrolment is Roma children's lack of being vaccinated.

In community centers, through community and social workers, I recommend carrying out educational activities for Roma parents in the following areas: health, the importance of vaccination, preventive examinations of children, adherence to hygiene.

\subsection{Language barrier}

Children and adults do not speak Slovak in both localities; their mother tongue is Roman. Kindergarten and school assistants work in Toporec and Vel'ká Lomnica. There is one Roma assistant in each institution. The parents of Roma children have great difficulties in dealing with official matters because of the language barrier.

The work of Roma assistants is needed, but the number of assistants (one in kindergarten and one in primary school) is very low, given the high number of children. Community and social workers also confirm that Roma parents do not speak Slovak. Parents use social services on a daily basis to communicate and deal with matters of urgency.

Parents assured me that they are aware of the requirements regarding the supplies and uniform requested by teachers. I informed them of the procedures and requirements. They had already received the information from the kindergarten and from the teacher's visit, where they had been informed of the procedures, and of the content of the enrollment file. No difference between boys and girls is made by either parents or teachers in the kindergarten and the primary school. However, the other parents said that they do not have enough capacity for children in the 
school. Regarding the enrollment in kindergarten, they insisted that all the children from the community are enrolled only in the oldest age group (5 years).

2. Barriers at the level of local authorities: Unequal approach, lack of investments, migration, etc.

For kindergartens, similarly to elementary schools, the only assistance in terms of extra support staff and funding of extracurricular activities targeting disadvantaged schools comes from so-called national projects funded from ESF. Almost 80 million EUR is allocated via Integrated Regional OP and 50 million EUR specifically targets areas with marginalized communities through Priority Axis 6 of the Operational Program Human Resources. In order for projects to be funded through this priority axis, they must ensure that at least $30 \%$ of enrolled children are Roma. Since 2016, the Ministry of Interior, administering this priority axis, contracted 19.3 EUR million for the development of 49 projects (expansion, renovation or development of new facilities) located in municipalities listed among the specifically targeted 150 localities with the least developed Roma communities. Another 7.8 EUR million was contracted for 32 projects in localities with marginalized communities outside the least developed 150 municipalities. Capacity expansion is also related to the fact, that pre-school education for all $5^{-}$ year-olds should be compulsory from 2021 onwards.

As in the school system, there are no rules and standards in the national reference framework for drawing on the European Social Fund to take account of desegregation and the creation of conditions for inclusive education. Their exhaustion therefore does not mean an effect, not to mention that they have almost no impact on improving the quality of education for the pupils themselves. However, the quality of education is not improving. The condition of participation in the National Project of Pre-school Education is that the kindergarten has enrolled at least five Roma children. However, there are many children in Roma settlements. The construction of kindergartens will help increase the capacity of Roma children, but these buildings are built in settlements and promote segregation.

\subsection{Meeting with the principals - Toporec}

Children and adults do not speak Slovak in both localities; their mother tongue is Romani. Both the kindergarten and the primary school in Toporec employ Roma assistants. There is one Roma assistant in each institution. Parents have great difficulties in dealing with official matters because of the language barrier. Therefore, they often use the services of community and social workers in their locations. This is a very good practice in the education sector, where there is good social assistance and support.

There are 2 kindergartens in Toporec. One is in the village, non-segregated, fully organized, 3 classes from 3-6 years. There is one Roma assistant in this kindergarten. The kindergarten is involved in the National Project of Supporting Pre-primary Education of Roma Children, which is funded by ESIF, implements this project by the Office of the Plenipotentiary of the Government for Roma Communities in cooperation with the municipality of Toporec. The number of Roma children enrolled in this kindergarten is 25 (15 boys and 10 girls). 17 children attend the kindergarten regularly. 8 children are enrolled on paper only, but in reality, they do not attend the kindergarten.

The second kindergarten is located about 3 kilometers from the village. The number of enrolled Roma children is 27 (14 boys and 13 girls). 14 children attend kindergarten regularly. This kindergarten is attended only by Roma children from the settlement. Officially, it is not a kindergarten, but a "Kids Club" as they say that they do not want to have problems due to 
segregating children. As these children would not attend a kindergarten in the village, distance is an obstacle. There is one teacher and one Roma assistant working in this kindergarten.

The municipality provides parents with a time limit for the payment of a monthly allowance of the child's legal representative in order to stay in kindergarten, which will be unified for all children. There is a method for the admission of children to pre-school education, as well as an age limit for their admission.

\subsection{Kindergarten in Toporec}

The principal stated that they have a responsibility to inform the parents about the registration of children and make a statement about the date of registration through the public radio. The principal cooperates with field social workers and community center workers. Enrollment of children in kindergartens took place from 15 February 2019 to 15 March 2019. And even after that date, until the capacity in kindergartens was filled. The parents were invited to enroll the children, through an invitation sent from the kindergarten director, along with instructions on what documents were needed to enroll the child. The following documents are required from the parents for the enrollment of their child: child's birth certificate, application form, medical certificate that the child is healthy and vaccinated.

A child between three and six years of age can be enrolled in a kindergarten. Exception can be applied for two-year-olds where capacities exist. Children older than 6 years can be enrolled in kindergarten for a maximum of 1 year. Children with postponement of pre-school education, can remain in kindergarten up to 7 years of age. Any child can enroll in a kindergarten in their place of residence. Those children are accepted first. Children can also be admitted in other kindergartens, away from their residence, provided the director agrees and has free capacities. Children for which education is compulsory have priority.

The municipality provides parents with a time limit for the payment of a monthly allowance of the child's legal representative in order to stay in kindergarten, which will be unified for all children. There is a method for the admission of children to pre-school education, as well as an age limit for their admission.

\subsection{Primary school in Toporec}

It is a fully organized school in the village that is not segregated. The total number of pupils attending primary school is $297.70 \%$ of them are Roma children. In the academic year 2020-2021, Toporec kindergarten will be attended by approximately 28 Roma children.

This school is also attended by children from nearby villages Jurské, Ihl'any, Holumnica from the fifth grade to the ninth grade of elementary school. 50 enrolled children do not attend primary school because they live abroad, most often in Ireland and England. There are no zero classes, the first class is attended by 27 pupils (14 boys and 13 girls). The classes are nonsegregated. Enrollment for the first year runs in April, from 1 to 30 April 2019. The parents were invited to enroll the children, by means of an invitation sent from the school director, along with instructions on what documents are needed to enroll the child. Documents required for enrollment: child's application and the birth certificate. Enrollment procedure includes a test of the readiness of the child to enter the first class. The test is performed with the child in the presence of the parent and lasts about 15 minutes.

The school principal said that they have cooperation with the municipality office to enroll the children, and that they have school assistants. They talk about the lack of interest of 
parents and children in education and say that they have good relationships with Roma parents and children.

\subsection{Special primary school in Toporec}

Special primary school in Toporec is a fully organized school located in the village for pupils from disadvantaged background. ${ }^{2}$ It is attended by only Romani pupils from Toporec. The number of children attending the special primary school is 76, out of which 46 are boys and 30 are girls. The reason for enrollment in a special school is the diagnosis of mental disability based on psychological testing.

One of the long-term educational strategies of school policy applied to Roma pupils in Slovak schools is the erroneous emphasis on "equality" in the name of liberalism and the promotion of equality. The fact that school politicians constantly confuse the notion of "equality" with "equally" causes schools to ignore socio-cultural differences. This approach leads to discrimination, in particular the segregation of Roma children, in respect of which the European Commission has been conducting proceedings against Slovakia since April 2015.3

\subsection{Meetings with parents}

Parents understand the need to educate their children, and some have agreed with me that if a person is educated, they will find it easier to find work if they have an apprenticeship certificate. Some families for unemployment and poor living conditions went abroad, some families stayed abroad, others returned home after several years, and invested the money saved in housing. But there are still many people living in the communitarians who live in the same conditions as their parents and grandparents. For many of them, daily survival is more important than enrolling their children in kindergarten. They do not have clothes, shoes for children, as they are mostly families with a high number of children. Currently, there are no longer poor families in the community, as those who did not migrate are employed, and those who did, made money abroad. The low level of the quality of life at all levels forces the Roma to go abroad. None of the children who have live abroad from Toporec attend a special school.

\subsection{Vel'ká Lomnica}

Enrollment of children in kindergartens took place from 29 April 2019 to 10 May 2019. The parents were invited to enroll their children via an invitation sent to them from the kindergarten director, along with instructions on what documents were needed to enroll the child. The following documents are required from the parent to complete enrolment: proof of health insurance and application form. The kindergarten in Vel'ká Lomnica is newly built, well equipped, teaching is in seven classes. They have one Roma assistant and one non-Roma assistant. The

\footnotetext{
2 Define it as an environment which, given social and linguistic conditions, does not sufficiently stimulate the development of the individual's mental, will and emotional qualities, does not support its effective socialization and does not provide adequate incentives for personality development. It causes socio-cultural deprivation, distorts the intellectual, moral and emotional development of the individual and for these reasons we consider him/her to be a person with special educational needs. (http://www.statpedu.sk/sk/svp/statny-vzdelavaci-program/vychova-vzdelavanie-ziakov-so-svvp/ziakso-sociane-znevyhodneneho-prostredia/).

3

https://tbinternet.ohchr.org/Treaties/CERD/Shared\%20Documents/SVK/INT CERD NGO SVK 2934 9 E.pdf.
} 
kindergarten is involved in the National Project of the Office of the Plenipotentiary of the Government of the Slovak Republic for Roma Communities. The capacity of the kindergarten is 120 children. There are 64 Roma children enrolled in kindergarten and 59 of them actually attend. 5 children are enrolled on paper only, but in reality, they do not attend kindergarten. Of these, 35 are boys and 24 are girls. This kindergarten is non-segregated, in a village approx. 2 kilometers from the settlement.

\subsection{Primary school in Vel'ká Lomnica}

The primary school is fully organized, non-segregated, located in the village approx. 2 kilometers from the settlement. The school is attended by 690 pupils. 468 are Roma children. 80 pupils are included in the zero classes ( 36 are girls and 44 boys). The first classes are attended by 21 pupils. These zero classes are attended only by Roma children. At school they introduced twoshift teaching for 8 classes at the first level. This caused an annual increase in the number of pupils. The parents were invited to enroll the children. The school director sent parents an invitation, along with instructions on what documents were needed to enroll the child. The documents required for enrollment: application and child's birth certificate. Enrollment also includes a school test of the readiness of the child to enter the first class. The test is performed with the child in the presence of the parent and lasts about 15 minutes.

\subsection{Meeting with the mayor Vel'ká Lomnica}

The mayor stated that the primary school is attended by 690 pupils. 468 are Roma (254 boys and 214 girls). 80 pupils are included in the zero classes, these zero classes are attended only by Roma children. In the academic year 2020-2021, the school will be attended by approximately 520 Roma children. In the locality, we register 4-5 families who have major problems with children's absence. They are mostly the poorest families. These families have dealt with social and legal protection of the children in cooperation with the police. The parents of these children will be imprisoned for 6 months. Learning outcomes have not been favorable in recent years. The mayor stated that another major shortcoming is the lack of responsibility among parents. He claimed that the low attendance is caused by parent's lack of responsibility. Despite the fact that all measures have been taken to improve participation, and the awareness that pupils who have missed one third of the lesson have no chance of mastering the curriculum, for parents, ale also for pupils, education does not hold the value that the majority attributes to it. Pupils lack motivation to achieve better results. This is also due to the lack of employment on the labor market.

There is a consensus that education is important, and everybody should be involved. Nevertheless, they recognized that there is persistent absenteeism and some dropouts among Roma children. In addition, although racism is not recognized in the community and among the authorities, I could hear two teachers saying that Roma do not value education, they receive social welfare and do nothing. Kindly, I told them that it is not fair to blame only Roma, but also the education system, which is not friendly, lacks qualified teachers (they said that this is true), lacks facilities, etc.

\subsection{Meeting with the principal}

The school principal told me that the parents enroll their children in the first classes, when children are 6 years old. Enrollment in the first class takes place at the school in April. Parents were invited to enroll their children in school. The principals sent an invitation to the parents, along with instructions on what documents were required to enroll the child. Schools 
send instruction and the application form to parents through social and community workers, who work with the municipal authority. They inform all parents about the dates of enrollment, through city radio, city magazine and they prepare a list of future pupils for schools. It is the parents' duty to come to school to enroll their child and bring the necessary documents. As part of the teacher is effort to improve the overall attendance, parents in the village of Vel'ká Lomnica were sent notifications of their children unexcused lessons. In front of everyone, by sending a notice of negligent school attendance, school violations, or by summoning the parents to the school for an interview. The principal of school Vel'ká Lomnica says that these shortcomings in education have resulted in low success rates in the fifth-class tests. This situation is due to the fact that more than half of the $5^{\text {th }}$ grade pupils come from the Roma community and have no motivation to learn. Pupils lack effort because they knew in advance that they would be admitted to study fields. For students who continue test results are not necessary.

\subsection{Meeting with the teacher preparatory class}

Children for whom pre-primary education is compulsory are usually placed in a separate class. Children with special educational needs are included in classes with other children or in separate classes for children with special educational needs. A child cannot be placed in a separate classroom for children with special educational needs solely because they come from a socially disadvantaged environment; if the one class consists of children from socially disadvantaged backgrounds, there may be a maximum of 16 children in the class. Separate classes can also be created for children learning a foreign language; the maximum number of children in this class is 12. Individual speech therapy is provided by a speech therapist who is an employee of educational counselling and prevention facilities.

Pre-primary education is primarily used for children for whom pre-primary education is compulsory. Other conditions of admission shall be determined by the principals of the kindergarten and published in a publicly accessible place or on the kindergarten's website. For a child with special educational needs, the application for admission of a child to pre-primary education shall be accompanied by the statement of the relevant educational counselling and prevention center and by the general practitioner for children and adolescents. A child from the age of three is admitted to pre-primary education; exceptionally, a child may be admitted from the age of two. A child from the age of two years can be admitted to pre-primary education if appropriate capacity, personnel, material and other conditions are created in the kindergarten.

The principal of the kindergarten decides on the admission of a child to pre-primary education in accordance with a special regulation. The principal of the kindergarten decides on the admission of a child by 15 June preceding the school year in which pre-primary education is to commence.

In the admission decision, the principals of the kindergarten may specify an adaptation stay, which may not be longer than three months or, in the case of the admission of a child with special educational needs, a diagnostic stay of the child, which may not be longer than three months. In the kindergarten for children with special educational needs, the diagnostic stay of the child must not exceed one year.

Compulsory pre-school education is provided for a child in a kindergarten in the municipality where he or she resides, unless the legal guardian or the representative of the child's establishment chooses another kindergarten. The child may also carry out compulsory pre-school education in other kindergartens where the child does not reside, if the principal of the kindergarten accepts it for pre-school education. 


\subsection{Meeting with the teacher - kindergarten}

The teacher knows the procedures, but she does not remember the dates. The children are enrolled because the teachers go from door to door when they do the census and, on this occasion, they enroll the children. The teacher told me that there is a family who has many children and does not value education and as a result, although enrolled, two of the children do not attend the kindergarten anymore. The teacher of the kindergarten school shall, in agreement with the founder, determine the place and date of submission of applications for admission to pre-primary education for the following school year and publish the conditions for admission pursuant.

The child is admitted to pre-primary education on the basis of a request from the legal guardian or representative of the facility, which he/she submits to the principal of the kindergarten, together with a certificate of medical fitness from the general practitioner for children and adolescents; the certificate of medical fitness of the child shall also contain an indication of the mandatory vaccination of the child. The application for admission of a child to pre-primary education is submitted from 1 to 31 May.

\subsection{Meeting with parents Vel'ká Lomnica}

The meeting was held in the community center. The mayor of the village was not present at the meeting with Roma parents. The mayor did not want to meet Roma parents because they wanted to talk to him about housing problems, water problems, etc. Roma parents discussed the process of enrollment in kindergarten and to the first class, the capacity to enroll all children, the relationships between parents and teachers, and whether the children are happy at school and how they feel there.

\section{Conclusions}

Recommendations on how to overcome the identified obstacles and to establish longterm solutions ensuring equal access of Roma children to quality and non-segregated education are the following:

- It is necessary to carry out educational activities for Roma parents in community centers. It is important that parents understand the need to lead children to independence. It is also important that community center staff facilitates meetings between parents and teachers and finds solutions and compromises.

- A campaign between teachers and parents to raise awareness about the importance of education. With regard to pre-school education, it is proposed that pre-school education will be mandatory from 3 years, because of the language barrier is a major problem. Other problems include the child's ability to adapt and commuting. It is necessary to carry out educational activities for Roma parents in Community Centers. It is important that parents understand the need to lead children to be more independent. It is also important that community center staff facilitate meetings between parents and teachers and find solutions and compromises.

- In community centers, through community and social workers, I recommend carrying out educational activities for Roma parents in the following areas: health, the importance of vaccination, preventive examinations of children, adherence to hygiene.

- I recommend working with Roma families through Roma assistants, social and community workers. Their numbers in kindergartens and primary 
schools need to be significantly increased. I would recommend compulsory pre-school education for a child from the age of three so that it can adapt to a new environment and learn to communicate well in the Slovak language.

- I would suggest further ongoing mapping of the enrollment situation and increasing awareness regarding preschool and primary school enrollment.

\section{Acknowledgements}

This research did not receive any specific grant from funding agencies in the public commercial, or not-for-profit sectors.

The author declares no competing interests.

\section{References}

Web sources:

http://www.statpedu.sk/sk/svp/statny-vzdelavaci-program/vychova-vzdelavanie-ziakov-sosvvp/ziak-so-sociane-znevyhodneneho-prostredia/)

https://tbinternet.ohchr.org/Treaties/CERD/Shared\%20Documents/SVK/INT_CERD_NGO_SVK _29349_E.pdf

https://eduroma.sk/publikacie.html

https://www.toporec.sk/

https://www.velkalomnica.sk/komunitne-centrum.html 
L. Mirgová - Analysis of Obstacles and Challenges Encountered by Parents in Roma Communities...

C O A $\mathrm{s}$ 